\title{
TP53 Codon 72 Polymorphism Is Associated with Coronary Artery Disease in Chilean Subjects
}

\author{
José Caamaño ${ }^{a-c}$ Nicolás Saavedra ${ }^{a, b}$ Priscilla C. Jaramillo ${ }^{a, b}$ Cecilia Lanas ${ }^{c}$ \\ Fernando Lanas ${ }^{b, c}$ Luis A. Salazar ${ }^{a, b}$ \\ a Laboratorio de Biología Molecular and Farmacogenética, Departamento de Ciencias Básicas, Facultad de \\ Medicina, ${ }^{b}$ Núcleo de Desarrollo Científico-Tecnológico en Biorecursos (BIOREN), and ' Departamento de Medicina \\ Interna, Facultad de Medicina, Universidad de La Frontera, Temuco, Chile
}

\section{Key Words}

Coronary artery disease $\cdot$ Gene polymorphism $\cdot$ TP53

\begin{abstract}
Objective: To investigate the possible association between the codon 72 polymorphism (Pro72Arg, rs1042522) of the tumor suppressor gene (TP53) and the presence of coronary artery disease (CAD) in Chilean subjects. Subjects and Methods: A total of 209 unrelated patients with a diagnosis of CAD confirmed by angiography (33-74 years old) and 216 healthy controls (30-68 years old) were included in this study. The Pro72Arg polymorphism of the TP53 gene was evaluated by PCR-RFLP. Results: The genotype distribution for the Pro72Arg variant of the TP53 gene in CAD patients (PP: $n=$ 13, 6.2\%; PR: $n=61,29.4 \%$; RR: $n=135,64.6 \%$ ) and controls (PP: $n=18,8.3 \%$; PR: $n=94,43.5 \%$; RR: $n=104,48.1 \%$ ) was significantly different $(p=0.003)$. Similarly, the allelic frequency was also different $(p=0.003)$. The odds ratio for CAD related to the $72 \mathrm{Arg}$ allele was $2.0(95 \% \mathrm{Cl}=1.33-2.90)$, confirming the presence of an association. Conclusion: These findings suggest that the Pro72Arg polymorphism of the TP53 gene is associated with CAD in Chilean individuals.
\end{abstract}

Copyright $\odot 2011$ S. Karger AG, Basel

\section{KARGER}

Fax +4161306 1234

E-Mail karger@karger.ch

www.karger.com
(C) 2011 S. Karger AG, Basel

1011-7571/11/0202-0171\$38.00/0

Accessible online at:

www.karger.com/mpp

\section{Introduction}

The molecular basis of coronary artery disease (CAD) is currently being investigated. Different genes have been implicated in the etiology of CAD $[1,2]$, including the TP53 gene [3]. The principal function of the TP53 gene is to guard cells against malignant transformation, prevent the proliferation of cells containing damaged DNA, and if repair is not possible, activate the mechanism by which tissues remove unwanted, aged, or damaged cells through the apoptotic pathway [4]. This mechanism has been related to the etiology of atherosclerotic lesion [5]; however, the role of TP53 is not completely understood.

The TP53 gene functions as an antioncogene, associated with upregulation of apoptosis [3]. TP53 wild type accumulates in atherosclerotic tissue and may mediate the apoptosis of vascular cells [6], and hence could regulate cell division and apoptosis within atherosclerotic plaque depending on the cell type and level of TP53 expression induced by DNA damage. Mutations that affect the TP53 gene can induce dysfunction of p53 and inhibit apoptosis and it has been hypothesized that loss of TP53 gene activity could play a relevant role in the pathogenesis of atherosclerosis [5]. A common polymorphism in

Prof. Luis A. Salazar, $\mathrm{PhD}$

Facultad de Medicina, Universidad de La Frontera

Av. Francisco Salazar 01145, Casilla 54-D

Temuco (Chile)

Tel. +56 45592 895, Fax +56 45592 832, E-Mail lsalazar@ufro.cl 
the TP53 gene, Pro72Arg (rs1042522), results in the occurrence of arginine (Arg) or proline (Pro) at codon 72 in the aminoacidic sequence of the protein. This polymorphism has been associated with various types of cancer [7-9] and lupus erythematosus [10]. Recently, the possible association with cardiovascular disease was also investigated [11-13]. However, the results are contradictory. In Chile, CAD is one of the main causes of death [14], but information related to the genetic basis of CAD in Chile is insufficient $[15,16]$. Thus, the aim of the present study was to evaluate the possible association between Pro72Arg gene polymorphism of the TP53 gene and CAD in Chilean subjects.

\section{Subjects and Methods}

\section{Subjects}

The Pro72Arg polymorphism was studied in 209 unrelated Chilean patients, aged 33-74 years, admitted to the Cardiology Service of the Hernán Henríquez Hospital of Temuco City, Chile, with angiographically determined coronary artery stenosis $>70 \%$. The control group consisted of 216 unrelated individuals, aged 30-68 years, from Temuco City. We used a structured questionnaire to identify disease-free controls and to exclude subjects who were suspected of having any form of vascular disease. Controls with a familial history of CAD, determined by interviewing, were excluded from the study. Demographic data and history of hypertension, diabetes mellitus, cigarette smoking, and hypercholesterolemia were assessed in each subject. In both groups, there was no preselection of serum lipid concentrations. Subjects with a history of diabetes or basal glycemia $\geq 126 \mathrm{mg} / \mathrm{dl}$ were defined as diabetic. The study protocol was approved by the Ethics Committee of our university, and all subjects gave written informed consents.

\section{Serum Measurements}

Biochemical measurements were determined from blood samples collected by venipuncture after overnight $(>12 \mathrm{~h})$ fast. Serum glucose, uric acid, triglycerides, total cholesterol and high-density lipoprotein cholesterol (HDL-C) levels were determined by enzymatic methods previously described [15]. Low-density lipoprotein cholesterol (LDL-C) was calculated using the Friedewald equation when the triglyceride concentrations did not exceed $400 \mathrm{mg} / \mathrm{dl}$.

\section{DNA Analysis}

Genomic DNA was extracted from blood leukocytes using the salting-out method optimized by Salazar et al. [17]. The Pro72Arg polymorphism of the TP53 gene was detected using polymerase chain reaction followed by enzymatic restriction according to conditions described by Smith et al. [11]. The correct assessment of genotypes for the Pro72Arg polymorphism of the TP53 gene was evaluated using a homozygous sample for the restriction site as a positive control. In addition, all gels were reread blindly by 2 persons (J.C. and L.S.) without any change, and $10 \%$ of the analyses were repeated randomly.
Table 1. Demographic and clinical characteristics of subjects with CAD (cases) and controls

\begin{tabular}{|c|c|c|c|}
\hline & $\begin{array}{l}\text { Cases } \\
(\mathrm{n}=209)\end{array}$ & $\begin{array}{l}\text { Controls } \\
(\mathrm{n}=216)\end{array}$ & $\mathrm{p}$ \\
\hline Age, years & $62 \pm 10$ & $42 \pm 8$ & $<0.001$ \\
\hline Male, $\%$ & 64 & 56 & 0.109 \\
\hline Diabetes, \% & 32 & 5 & $<0.001$ \\
\hline Systolic blood pressure, $\mathrm{mm} \mathrm{Hg}$ & $140 \pm 26$ & $125 \pm 23$ & $<0.001$ \\
\hline Diastolic blood pressure, $\mathrm{mm} \mathrm{Hg}$ & $80 \pm 18$ & $75 \pm 9$ & 0.020 \\
\hline Body mass index, $\mathrm{kg} / \mathrm{m}^{2}$ & $28.2 \pm 4.5$ & $25.8 \pm 4.5$ & $<0.001$ \\
\hline Smoking, \% & 64 & 41 & $<0.001$ \\
\hline Hypercholesterolemia, \% & 80 & 20 & $<0.001$ \\
\hline Hypertension, \% & 79 & 26 & $<0.001$ \\
\hline Angina, \% & 77 & 0 & $<0.001$ \\
\hline AMI, \% & 66 & 0 & $<0.001$ \\
\hline Familial history of CAD, \% & 32 & 0 & $<0.001$ \\
\hline \multicolumn{4}{|l|}{ Number of diseased vessels, $\%$} \\
\hline Single vessel & 31 & 0 & - \\
\hline Double vessel & 28 & 0 & - \\
\hline Triple vessel & 41 & 0 & - \\
\hline Total cholesterol, mg/dl & $214 \pm 51$ & $175 \pm 33$ & $<0.001$ \\
\hline LDL-C, mg/dl & $127 \pm 42$ & $95 \pm 27$ & $<0.001$ \\
\hline $\mathrm{HDL}-\mathrm{C}, \mathrm{mg} / \mathrm{dl}$ & $32 \pm 8$ & $49 \pm 12$ & $<0.001$ \\
\hline Triglycerides, mg/dl & $181 \pm 92$ & $114 \pm 86$ & $<0.001$ \\
\hline Fasting glucose, $\mathrm{mg} / \mathrm{dl}$ & $113 \pm 42$ & $94 \pm 37$ & $<0.001$ \\
\hline Uric acid, mg/dl & $5.6 \pm 1.6$ & $4.5 \pm 1.5$ & $<0.001$ \\
\hline
\end{tabular}

$\mathrm{AMI}=$ Acute myocardial infarction. $\mathrm{p}$ values from Student $\mathrm{t}$ test or $\chi^{2}$ test.

\section{Statistical Analysis}

Statistical analysis was carried out using the Sigma Stat Software, version 2.0 (Jandel Sci., San Rafael, Calif., USA). Data are presented as mean \pm SD. Differences between the means of continuous variables were evaluated by Student $t$ test or one-way ANOVA. The allelic frequencies and genotype distribution were estimated by gene counting. Differences between noncontinuous variables and Hardy-Weinberg equilibrium were tested by $\chi^{2}$ analysis. The odds ratio (OR) and 95\% confidence interval (CI) associated with the mutated $72 \mathrm{R}$ allele were also calculated. Statistical significance was set at $\mathrm{p}<0.05$.

\section{Results}

\section{Clinical Variables}

The clinical, anthropometric and laboratory characteristics of the study subjects are given in table 1 . The CAD subjects had elevated values of body mass index and a higher prevalence of traditional risk factors, including smoking, diabetes, hypertension, hypercholesterolemia and familial history of CAD ( $p<0.001)$. The baseline se- 
Table 2. Genotype distribution and relative allele frequencies of the Pro72Arg polymorphism of TP53 in Chilean subjects with CAD (cases) and controls

\begin{tabular}{lllllll}
\hline & \multicolumn{2}{l}{ Genotype } & & \multicolumn{3}{l}{ Allele } \\
\cline { 2 - 3 } \cline { 5 - 6 } & PP & PR & RR & & P & $\mathrm{R}$ \\
\hline Cases $(\mathrm{n}=209)$ & $13(6.2 \%)$ & $61(29.2 \%)$ & $135(64.6 \%)$ & & 0.208 & 0.792 \\
Controls $(\mathrm{n}=216)$ & $18(8.3 \%)$ & $94(43.5 \%)$ & $104(48.1 \%)$ & & 0.301 & 0.699 \\
& $\chi^{2}=11.74 ; 2$ & d.f.; $\mathrm{p}=0.003^{\mathrm{a}}$ & & & $\chi^{2}=9.14 ; 1$ d.f.; $\mathrm{p}=0.003$ \\
\hline
\end{tabular}

d.f. $=$ Degree of freedom.${ }^{\text {a }}$ Power of performed test with $\alpha=0.050: 0.888$.

rum concentrations of triglycerides, total cholesterol, LDL-C, glucose and uric acid were higher in CAD patients than controls $(p<0.05)$. Similarly, the CAD subjects exhibited elevated values of systolic and diastolic blood pressure $(\mathrm{p}<0.05)$. In addition, CAD subjects presented lower HDL-C concentrations $(\mathrm{p}<0.001)$.

\section{Allele Frequencies}

The genotype distribution and the relative allele frequency of the Pro72Arg polymorphism of the TP53 gene in CAD patients and controls are given in table 2 . The genotype distribution was as expected from the HardyWeinberg equilibrium for CAD and control subjects (CAD, $\chi^{2}=2.743, \mathrm{p}=\mathrm{NS}$ and controls, $\chi^{2}=0.255, \mathrm{p}=\mathrm{NS}$ ), similar to previous data observed in a Chilean adult population sample $[8,9]$. The genotype distribution for the Pro72Arg polymorphism in CAD patients and controls was significantly different $(p=0.003)$. Moreover, the relative allelic frequency was different in both groups $(\mathrm{p}=$ 0.003 ). The OR for CAD related to the 72Arg allele was $2.0(95 \% \mathrm{CI}=1.33-2.90)$ confirming the presence of association. However, we did not find any association between traditional risk factors for CAD and the different genotypes of the Pro72Arg polymorphism of the TP53 gene (table 3). In addition, a comparison of studies involving different populations with our study is given in table 4 .

\section{Discussion}

Several genes have been related to the etiology of CAD $[1,2]$, including the tumor suppressor gene TP53 [18]. A common polymorphism in TP53, Pro72Arg, has been the focus of analysis in CAD; nevertheless, the results were discordant $[11,12]$. Thus, in the present study,
Table 3. Clinical and demographic characteristics of subjects with CAD according to Pro72Arg genotypes of the TP53 gene

\begin{tabular}{lcccc}
\hline & $\begin{array}{l}\mathrm{PP} \\
(\mathrm{n}=13)\end{array}$ & $\begin{array}{l}\mathrm{PR} \\
(\mathrm{n}=61)\end{array}$ & $\begin{array}{l}\mathrm{RR} \\
(\mathrm{n}=135)\end{array}$ & $\mathrm{p}$ \\
& $60 \pm 13$ & $62 \pm 12$ & $63 \pm 11$ & 0.425 \\
\hline Age, years & $27 \pm 4.6$ & $28 \pm 5.1$ & $28 \pm 4.4$ & 0.937 \\
Body mass index, kg/m ${ }^{2}$ & $127 \pm 23$ & $138 \pm 24$ & $142 \pm 27$ & 0.421 \\
SBP, mm Hg & $75 \pm 13$ & $74 \pm 11$ & $74 \pm 9$ & 0.976 \\
DBP, mm Hg & 32 & 35 & 28 & 0.674 \\
Diabetes, \% & 80 & 79 & 81 & 0.911 \\
Hypercholesterolemia, \% & 79 & 80 & 78 & 0.913 \\
Hypertension, \% & 30 & 34 & 30 & \\
Number of diseased vessels, \% & & & \\
$\quad$ Single vessel & 30 & 34 & 19 & 0.090 \\
$\quad$ Double vessel & 40 & 32 & 51 & \\
$\quad$ Triple vessel & $199 \pm 45$ & $200 \pm 41$ & $206 \pm 28$ & 0.937 \\
Total cholesterol, mg/dl & $128 \pm 23$ & $130 \pm 34$ & $135 \pm 15$ & 0.915 \\
LDL-C, mg/dl & $29 \pm 9$ & $32 \pm 8$ & $33 \pm 8$ & 0.520 \\
HDL-C, mg/dl & $216 \pm 100$ & $184 \pm 169$ & $181 \pm 49$ & 0.809 \\
Triglycerides, mg/dl & $111 \pm 49$ & $108 \pm 30$ & $115 \pm 47$ & 0.785 \\
Fasting glucose, mg/dl & $5.6 \pm 1.2$ & $5.8 \pm 1.9$ & $5.5 \pm 1.5$ & 0.782 \\
Uric acid, mg/dl & & & & \\
\hline
\end{tabular}

$\mathrm{DBP}=$ Diastolic blood pressure $\mathrm{SBP}=$ systolic blood pressure. $p$ values from one-way ANOVA or $\chi^{2}$ test.

we have investigated the possible association between the Pro72Arg polymorphism and CAD in Chilean individuals. The analysis of clinical and laboratory parameters in both groups showed that serum concentrations of total cholesterol, LDL-C, triglycerides, glucose and uric acid were higher in CAD than control subjects. In addition, the HDL-C concentrations were lower in the CAD group. These results show a significant association between these traditional risk factors and CAD as previously reported [19]. 
Table 4. Comparison of different studies of the Pro72Arg polymorphism of the TP53 gene

\begin{tabular}{llllll}
\hline Reference & Study design & $\begin{array}{l}\text { Cases/ } \\
\text { controls }\end{array}$ & Ethnicity & $\begin{array}{l}\text { CVD } \\
\text { diagnosis }\end{array}$ & $\begin{array}{l}\text { Frequency of 72R, } \\
\text { cases/controls }\end{array}$ \\
\hline Smith et al. [11] & case-control $^{1}$ & $383 / 56$ & diverse $^{2}$ & diverse $^{3}$ & $0.693 / 0.759$ \\
with CVD
\end{tabular}

CVD $=$ Cardiovascular disease

${ }^{1}$ Matched by age.

2 The cases group was composed of individuals of European (89.2\%), Japanese (3.3\%), Middle Eastern (1.81\%), and mixed and/ or other origin (5.70\%). The mean age of this population cohort was $79.80 \pm 5.32$ years (range: $66-97$ years). The elderly control sample was composed of $89.3 \%$ European, $5.4 \%$ Japanese, $1.8 \%$ Afro-Brazilian, and 3.5\% mixed origin subjects.

${ }^{3}$ Subjects were considered positive for cardiovascular disease when they self-reported previous myocardial infarction and/or coronary heart disease, cerebrovascular disease and/or transitory ischemic attacks and were also taking specific medication prescribed by physicians.

${ }^{4}$ Matched by age and gender.

${ }^{5} \mathrm{CAD}$ was confirmed by cardiac catheterization.

${ }^{6}$ Not matched by gender.

${ }^{7}$ CAD documented by angiography.

${ }^{8}$ Matched by gender.

${ }^{9} \mathrm{CAD}$ documented by angiography (coronary artery stenosis $>70 \%$ ).
Our findings also exhibit a significant association between CAD and the $72 \mathrm{R}$ allele (Arg72 variant) of the Pro72Arg polymorphism of the TP53 gene $(\mathrm{OR}=2.0,95 \%$ $\mathrm{CI}=1.33-2.90)$. The frequency of the $\mathrm{R}$ allele was higher in CAD subjects than controls ( 0.79 vs. $0.69, \mathrm{p}=0.003)$ similar to the study by Kojima et al. [20], in which there was a significant association between the homozygous Arg/Arg genotype and coronary luminal narrowing. Furthermore, Bonafé et al. [21] showed that individuals carrying the Arg variant exhibited higher levels of CK$\mathrm{MB}$ and troponin I, both biochemical markers of myocardial injury as they had previously shown that the $72 \mathrm{Arg}$ variant is associated with restenosis after angioplasty [22]. Accordingly, the TP53 codon 72 polymorphism seems to contribute to a genetically determined variability in atherosclerosis. However, Manfredi et al. [13], Smith et al. [11] and Alkhalaf et al. [12] did not find any association between the Pro72Arg polymorphism and the occurrence of CAD in Italian, Brazilian and Kuwaiti subjects, respectively, but Manfredi et al. [13] and Smith et al. [11] detected an association between the 72Arg allele and lower levels of HDL-C. The reasons for these discrepancies include the differences in the study design, the definition of inclusion and exclusion criteria, the number of participants, and the different ethnicities of subjects as show in table 4.

In relation to the possible mechanisms that can explain our findings, it is important to mention that the Pro72Arg polymorphism affects the proline-rich domain of p53, a sequence necessary for the transmission of antiproliferative signals, and it has been suggested that the 2 alleles may produce functionally distinct proteins with differences in their capacity to activate gene expression [23]. Dumont et al. [24] established that the 72Arg variant is more efficient in inducing apoptosis, probably caused by a better interaction with the p53 binding protein homolog (MDM2), facilitating the nuclear exportation and mitochondrial localization of p53. In addition, the Pro72Arg polymorphism has been associated with interindividual variation in apoptotic response. In atherosclerotic plaque, reactive oxygen species are responsible for DNA damage [5], and a single rupture in a doublestranded DNA molecule may be sufficient to prompt a rise in levels of p53 [25]. Apoptosis in endothelial cells have been related to plaque instability and thrombus formation [26]. A disturbance in the apoptotic response may lead to accumulation of intimal cells through atherogenesis [5]. The functional consequence of the Pro72Arg polymorphism has been related to inhibition of $\mathrm{p} 73$ function, a member of the p53 family of nuclear transcription factors, implicated in tumor suppression [27]. The Arg polymorphic allele is more efficient in binding to p73, blocking its action and facilitating the proliferation of vascular smooth muscle cells $[27,28]$.

Based on the above mechanism, it is probable that CAD individuals carrying the Arg variant of the TP53 Pro72Arg polymorphism are more susceptible to suffer deregulation of apoptosis during atherosclerosis progres- 
sion, and consequently, promote the development of CAD. This explanation is similar to that offered for the Pro72Arg polymorphism in the different types of cancers, particularly cervical and lung cancers $[8,9,29]$. Interestingly, the allelic frequency for the Pro72Arg polymorphism of TP53 observed in 60 Chilean patients with cervical cancer [8] and in 111 patients with lung cancer [9] was similar to that in patients with CAD evaluated in our study. According to Ojeda et al. [8], the world distribution of this polymorphism reflects ancient human migration routes, more specifically the dispersal of modern Homo sapiens out of Africa some 100,000-150,000 years ago. The high frequency of the 72Arg allele in Central and South America contradicts the hypothesis of Beckman et al. [30] that the world distribution of this polymorphism reflects an adaptation to ultraviolet radiation. Thus, the high frequency of this polymorphism in Chile can be explained, at least in part, by the present results and why no such associations were found in other countries.

\section{Conclusion}

The present study showed an association between CAD and TP53 codon 72 polymorphism in Chilean subjects indicating that this genetic variation could be a genetic marker for CAD in Chile. However, this study is restricted by the use of controls not matched by age. In addition, this observation needs to be replicated in other population groups.

\section{Acknowledgements}

This study was supported by grants from Dirección de Investigación y Desarrollo, Universidad de La Frontera (DI09-1007). J.C. was the recipient of a fellowship from MIDEPLAN, Chile.

\section{References}

1 Wang Q: Molecular genetics of coronary artery disease. Curr Opin Cardiol 2005;20: 182-188.

2 Peters RJ, Boekholdt SM: Gene polymorphisms and the risk of myocardial infarction - An emerging relation. $\mathrm{N}$ Engl J Med 2002;347:1963-1965.

3 Geng YJ: Molecular signal transduction in vascular cell apoptosis. Cell Res 2001;11: 253-264.

4 Bose I, Ghosh B: The p53-MDM2 network: from oscillations to apoptosis. J Biosci 2007; 32:991-997.

5 Mercer J, Mahmoudi M, Bennett M: DNA damage, p53, apoptosis and vascular disease. Mutat Res 2007;621:75-86.

6 Ihling C, Haendeler J, Menzel G, Hess RD, Fraedrich G, Schaefer HE, Zeiher AM: Coexpression of $\mathrm{p} 53$ and MDM2 in human atherosclerosis: implications for the regulation of cellularity of atherosclerotic lesions. J Pathol 1998;185:303-312.

7 Pinto GR, Yoshioka FK, Silva RL, Clara CA, Santos MJ, Almeida JR, Burbano RR, Rey JA, Casartelli C: Prognostic value of TP53 Pro47Ser and Arg72Pro single nucleotide polymorphisms and the susceptibility to gliomas in individuals from Southeast Brazil. Genet Mol Res 2008;7:207-216.

8 Ojeda JM, Ampuero S, Rojas P, Prado R, Allende JE, Barton SA, Chakraborty R, Rothhammer F: p53 codon 72 polymorphism and risk of cervical cancer. Biol Res 2003;36:279283.
-9 Irarrázabal CE, Rojas C, Aracena R, Márquez C, Gil L: Chilean pilot study on the risk of lung cancer associated with codon 72 polymorphism in the gene of protein $\mathrm{p} 53$. Toxicol Lett 2003;144:69-76.

10 Piotrowski P, Lianeri M, Mostowska M, Wudarski M, Chwalinska-Sadowska H, Jagodzinski PP: Contribution of polymorphism in codon 72 of p53 gene to systemic lupus erythematosus in Poland. Lupus 2008; 17:148151.

11 Smith MA, Silva MD, Cendoroglo MS, Ramos LR, Araujo LM, Labio RW, Burbano RR, Chen ES, Payão SL: TP53 codon 72 polymorphism as a risk factor for cardiovascular disease in a Brazilian population. Braz J Med Biol Res 2007;40:1465-1472.

12 Alkhalaf M, Al-Bustan S, Hamoda H, Abdella N: Polymorphism of p53 gene codon 72 in Kuwaiti with coronary artery disease and diabetes. Int J Cardiol 2007;115:1-6.

13 Manfredi S, Masetti S, Botto N, Colombo MG, Terrazzi M, Vassalle C, Biagini A, Andreassi MG: P53 codon 72 polymorphism in coronary artery disease: no evidence for association with increased risk or micronucleus frequency. Environ Mol Mutagen 2002; 40:110-115

- 14 Lanas F, Avezum A, Bautista LE, Diaz R, Luna M, Islam S, Yusuf S, INTERHEART Investigators in Latin America: Risk factors for acute myocardial infarction in Latin America: the INTERHEART Latin American study. Circulation 2007;115:1067-1074.
-15 Jaramillo PC, Muñoz A, Lanas C, Lanas F, Salazar LA: Endothelial nitric oxide synthase G894T gene polymorphism in Chilean subjects with coronary artery disease and controls. Clin Chim Acta 2006;371:102-106.

16 Caamaño J, Jaramillo PC, Lanas C, Lanas F, Salazar LA: Factor XII 46C $>$ T gene polymorphism in Chilean subjects with coronary artery disease and controls. Med Princ Pract 2009; 18:137-142.

-17 Salazar LA, Hirata MH, Cavalli SA, Machado MO, Hirata RD: Optimized procedure DNA isolation from fresh and cryopreserved clotted human blood useful in clinical molecular testing. Clin Chem 1998;44:17481750.

18 Tabas I: p53 and atherosclerosis. Circ Res 2001;88:747-749.

19 Executive summary of the third report of the National Cholesterol Education Program (NCEP) expert panel on detection, evaluation, and treatment of high blood cholesterol in adults (Adult Treatment Panel III). JAMA 2001;285:2486-2497.

20 Kojima S, Goto Y, Nonogi H, Horie H, Kinoshita M, Iwai N: Role of a p53 polymorphism in luminal narrowing after balloon coronary angioplasty. Atherosclerosis 2000; $151: 585-586$ 
21 Bonafé M, Salvioli S, Barbi C, Trapassi C, Tocco F, Storci G, Invidia L, Vannini I, Rossi M, Marzi E, Mishto M, Capri M, Olivieri F, Antonicelli R, Memo M, Uberti D, Nacmias B, Sorbi S, Monti D, Franceschi C: The different apoptotic potential of the p53 codon 72 alleles increases with age and modulates in vivo ischaemia-induced cell death. Cell Death Differ 2004;11:962-973.

22 Bonafé M, Olivieri F, Mari D, Baggio G, Mattace R, Berardelli M, Sansoni P, De Benedictis G, De Luca M, Marchegiani F, Cavallone L, Cardelli M, Giovagnetti S, Ferrucci L, Amadio L, Lisa R, Tucci MG, Troiano L, Pini G, Gueresi P, Morellini M, Sorbi S, Passeri G, Barbi C, Valensin S, Monti D, Deiana L, Pes GM, Carru C, Franceschi C: P53 codon 72 polymorphism and longevity: additional data on centenarians from continental Italy and Sardinia. Am J Hum Genet 1999;65: 1782-1785.
23 Thomas M, Kalita A, Labrecque S, Pim D, Banks L, Matlashewski G: Two polymorphic variants of wild-type p53 differ biochemically and biologically. Mol Cell Biol 1999;19: 1092-1100.

24 Dumont P, Leu JI, Della Pietra AC 3rd, George DL, Murphy M: The codon 72 polymorphic variants of p53 have markedly different apoptotic potential. Nat Genet 2003; 33:357-365.

25 Vogelstein B, Lane D, Levine AJ: Surfing the p53 network. Nature 2000;408:307-310.

26 Kavurma MM, Bhindi R, Lowe HC, Chesterman C, Khachigian LM: Vessel wall apoptosis and atherosclerotic plaque instability. J Thromb Haemost 2005;3:465-472.
7 Marabese M, Vikhanskaya F, Broggini M: p73: a chiaroscuro gene in cancer. Eur J Cancer 2007;43:1361-1472.

28 Kojima S, Iwai N, Tago N, Ono K, Ohmi K, Tsujimoto G, Takagi S, Miyazaki S, Nonogi $\mathrm{H}$, Goto Y: p53Arg72Pro polymorphism of tumour suppressor protein is associated with luminal narrowing after coronary stent placement. Heart 2004;90:1069-1070.

29 Storey A, Thomas M, Kalita A, Harwood C, Gardiol D, Mantovani F, Breuer J, Leigh IM, Matlashewski G, Banks L: Role of a p53 polymorphism in the development of human papillomavirus-associated cancer. Nature 1998;393:229-234.

30 Beckman G, Birgander R, Själander A, Saha N, Holmberg PA, Kivelä A, Beckman L: Is p53 polymorphism maintained by natural selection? Hum Hered 1994;44:266-270. 